\title{
Henryka SĘDZIAK
}

\section{DZIERŻAWCZE NAZWY WSI DROBNOSZLACHECKICH W ŁOMŻYŃSKIEM}

Niniejszy artykuł jest trzecim z cyklu opracowań nazw wsi drobnej szlachty ziemi łomżyńskiej. Pierwsze dwa artykuły ${ }^{1}$ poświęcone były opisowi nazw rodowych, najliczniejszych w tym regionie, stanowiących $56,7 \%$ ogółu nazw wsi szlachty zagrodowej. Nazwy dzierżawcze są tu mniej liczne, wynoszą 21,8\%.

Nazwy dzierżawcze "oznaczają miejscowość będącą ongiś własnością człowieka, od którego imienia urobiono nazwę" 2. Autorzy encyklopedii Polskie nazwy własne uszczegółowiają tę definicję następująco: „nazwy miejscowe tworzone od nazw osobowych (imion, przezwisk lub nazwisk) za pomocą derywacji słowotwórczej (sufiksalnej), oznaczają zaś miejscowość będącą własnością osoby, której imię stało się podstawą nazwy. Nazwy dzierżawcze powstają najczęściej za pomocą przyrostków (sufiksów) przymiotnikowych: *-jb $\left({ }^{*}-j a,{ }^{*}\right.$-je), ${ }^{*}$-ovъ $\left({ }^{*}\right.$-ova, -owo)//*-'еvъ (*-'eva, *'evo) oraz *-inъ $\left({ }^{*}\right.$-ina, *-ino)" 3 .

Klasyfikowanie nazw miejscowych uformowanych za pomocą wymienionych przyrostków rodzi poważne trudności. Zwrócił na to uwagę Witold Taszycki ${ }^{4}$, dowodząc, że przyrostki -ów, -owa, -owo albo -ew, -ewa, - ewo oraz -in, -ina, -ino mogą tworzyć nazwy dzierżawcze wskazujące właściciela osady lub nazwy topograficzne informujące o właściwościach terenu. W późniejszej swej pracy Taszycki ${ }^{5}$ stwier-

1 H. Sędziak, Rodowe nazwy wsi drobnoszlacheckich w Łomżyńskiem (w druku); także, Nazwy złożone wsi drobnoszlacheckich $w$ ziemi łomżyńskiej, „Białostockie Archiwum Językowe” 2, red. B. Nowowiejski, Białystok 2002, s. 117-129.

2 W. Taszycki, Stowiańskie nazwy miejscowe. Ustalenie podziału, Kraków 1946, s. 45.

3 Polskie nazwy własne. Encyklopedia, red. E. Rzetelska-Feleszko, Warszawa - Kraków 1998, s. 203.

4 W. Taszycki, Rzekomo dzierżawcze nazwy miejscowe, "Język Polski" 1937, s. 104-111.

5 W. Taszycki, Stowiańskie nazwy..., op. cit., s. 45-46. 
dza, że zaliczenie nazwy miejscowej utworzonej za pomocą wymienionych wyżej przyrostków do grupy nazw dzierżawczych nie sprawia trudności tylko wówczas, kiedy nazwa pochodzi od niewątpliwego imienia czy przezwiska. Karol Zierhoffer ${ }^{6}$ uważa, że przy wątpliwościach, czy mamy do czynienia z nazwą topograficzną, czy dzierżawczą, o charakterze konkretnego toponimu często muszą rozstrzygać względy pozajęzykowe. O utworzeniu nazwy miejscowej typu topograficznego decydował, według Zierhoffera, trwały element krajobrazu, np. rzeka, drzewo. Zwierzę natomiast jako niestały składnik fizjografii terenu rzadko stać się mogło podstawą nazwy miejscowej. Zdaniem Zierhoffera, nazwa Turowo utworzona została nie od apelatywu, ale od nazwy osobowej Tur. Stanisław Rospond, widząc, z jakimi trudnościami borykają się językoznawcy, którzy chcą kwalifikować nazwy, stosując typologię leksykalno-znaczeniową, zaproponował klasyfikację strukturalną, uwzględniającą nie tylko formę, ale i funkcję przyrostków, czyli wydzielającą typy strukturalne ${ }^{7}$. W tej klasyfikacji nazwy dzierżawcze mieszczą się wśród nazw sekundarnych o derywacji sufiksalnej.

Przedmiotem niniejszego opracowania są nazwy dzierżawcze wsi drobnoszlacheckich $\mathrm{z}$ dwóch powiatów historycznej ziemi łomżyńskiej, powiatu łomżyńskiego i zambrowskiego. Tereny tego ostatniego w wieku XIX i w pierwszej połowie wieku XX (do 1954 roku) wchodziły w skład pow. łomżyńskiego. Poza nim znalazła się (przypisana od stycznia 1999 roku do pow. białostockiego) mazowiecka gmina Zawady (niegdyś gm. Chlebiotki) ${ }^{8}$, stanowiąca integralną część ziemi łomżyńskiej i wiskiej. Obszar tej gminy zamyka rzeczka Ślina dzieląca Mazowsze od Podlasia ${ }^{9}$.

Jak już wspomniano, tylko 21,8\% nazw wsi drobnej szlachty na badanym terenie stanowią nazwy dzierżawcze. Wśród 68 wsi mających

6 K. Zierhoffer, Nazwy miejscowe pótnocnego Mazowsza, Wrocław 1957, s. 20.

7 S. Rospond, Klasyfikacja strukturalno-gramatyczna stowiańskich nazw geograficznych, Wrocław 1957 , s. 28 i n.

8 Od wielu lat $\mathrm{z}$ inicjatywy $Ł T N$ im. Wagów prowadzone są badania językowe i nazewnicze dawnej ziemi łomżyńskiej i wiskiej, nie rezygnujemy więc $z$ obszaru naszych badań mimo zmiany granic administracyjnych.

9 A. Wolff, Ziemia tomżyńska $w$ średniowieczu, Łomża 1988, s. 12. 
nazwy dzierżawcze jest 9 nazw, w których powtarza się człon podstawowy, np. Krajewo (Białe, Borowe, -Korytki, -Łętowo, Stare), Maliszewo (-Łynki, -Perkusy), Ratowo (-Piotrowo, Stare). Nazwy te są wynikiem procesu rozpadania się wsi szlacheckich na działy, które z czasem stawały się odrębnymi wsiami, zachowując podstawową nazwę dzierżawczą z dodanym członem wyróżniającym. Nazwy powtarzające się obejmują łącznie 25 wsi. Ogółem nazw złożonych z pierwszym członem dzierżawczym jest 41, co stanowi 60,3\% nazw dzierżawczych na badanym terenie.

Interesujący dla historii osadnictwa i rozwoju nazw wsi wydaje się fakt, że w pow. zambrowskim nazw złożonych dwu-i trójczłonowych jest aż 28 (87,5\% nazw dzierżawczych w tym powiecie), zaś w pow. łomżyńskim - tylko 10 (30,3\%). Historyk regionu Małgorzata Dajnowicz, autorka pracy o drobnej szlachcie ziemi łomżyńskiej ${ }^{10}$, uważa, że ma to związek z wielkością nadań książęcych, gdyż tylko wielkie nadania obszarów ziemi, borów mogły się stać podstawą powstania kilku wsi, zachowujących nazwę wskazującą imię lub nazwisko pierwszego właściciela.

Do opracowania nazw dzierżawczych w Łomżyńskiem wykorzystane zostały następujące źródła ${ }^{11}$ : Herbarz Ignacego Kapicy-Milewskiego, Źródła dziejowe... Adolfa Pawińskiego, Słownik geograficzny Królestwa Polskiego, Dawna ziemia łomżyńska Zygmunta Glogera, Metryka Księstwa Mazowieckiego, Mazowieckie zapiski herbowe i Ziemia łomżyńska w średniowieczu Adama Wolffa, Najdawniejsze polskie imiona osobowe i Stownik staropolskich nazw osobowych Witolda Taszyckiego.

Cennych informacji o nazwach miejscowych badanego terenu dostarczyły prace Karola Zierhoffera ${ }^{12}$ i Ireny Halickiej ${ }^{13}$.

Ze względu na wąskie ramy artykułu konieczne jest ograniczenie opisu nazw do wybranych przykładów z każdej grupy derywatów.

10 M. Dajnowicz, Drobna szlachta ziemi łomżyńskiej na przełomie XI i XX wieku, Łomża 2002.

11 Wykaz źródeł i objaśnienie skrótów znajduje się na końcu artykułu.

12 K. Zierhoffer, op. cit.

13 I. Halicka, Nazwy miejscowe środkowej i zachodniej Białostocczyzny, cz. 1, 2, Warszawa 1976, 1978. 
1. Nazwy z sufiksem -ov-//-'ev-

Najbardziej produktywnym formantem $\mathrm{w}$ tworzeniu nazw dzierżawczych jest tu sufiks -ov-//-'ev-. Tworzy on 61,6\% badanych nazw dzierżawczych. "Nazwy dzierżawcze z -ov-//-'ev- są szczególnie częste w Polsce północnej” ${ }^{14}$. W analizowanych nazwach miejscowych sufiks ten występuje tylko w rodzaju nijakim (-owo, -ewo).

Braciszewo, dziś Brajczewo-Sierzputy wś szlach. i włośc. (1441), pow. i gm. Zambrów: SG I 349; Glog 11; „Dom Braciszewskich h. Zagłoba czy Zagroby" Kap nr 21; Braczischewsky 1432 MkM II nr 358; de Braczyschewo 1422 MZH nr 195; Braycziszewo 1578 ŹDz XVI 381; Zierh 120; Hal Bł I 25. Braciszewo n. dzierż. od n. os. Bracisz ( $\leq$ Bratumit). Por. im. Braciesz TNaj 67. Braciszewo $\geq$ Brajczewo. Sierzputy n. rod. od n. os. Sierzput.

Brzostowiec, dziś Brzostowo (-Nadbory) okolica szlachecka nad rzeką Biebrzą, pow. Łomża, gm. Jedwabne: SG I 422; "gniazdo Brzostowskich h. Konopki" Kap nr 26; Brzostowecz 1427 MkM I nr 470; Nadborii de Brzostowo de armis Konopky $1481 \mathrm{MZH}$ nr 586; Brzostowo 1577 ŹDz XVI 356; Zierh 125; Hal Bł I 28. Brzostowo n. dzierż. od n. os. Brzost. Por. Nicolo Brost 1366; Ablertus Brosth 1483 TS. Zierh: n. top. od n. ap. brzost 'gatunek wiązu'. Nadbory n. rod. od im. Nadbor (Nadborius) dziś już nie stosowana.

Chmielowo wś szlach., pow. Łomża, gm. Nowogród: SG I 587; Glog 11; Chmelewo 1428 MkM I nr 685; de Chmyelevo $1500 \mathrm{MZH}$ nr 800, 802; Chmielewo 1578 ŹDz XVI 371; Zierh 132; Hal Bł I 32. Chmielewo n. dzierż. od n. os. odapelatywnej Chmiel. Zierh: n. top. lub n. dzierż.

Chrostowo (Wielkie) wś szlach. (1477), pow. Łomża, gm. Jedwabne: SG I 647; Glog 11; Kap nr 63; Chrostowo 1425 MkM I nr 165; de Chrosthowo 1489 MZH nr 681; Chrostowo 1577 ŹDz XVI 358; Zierh 136; Hal Bł I 35. Chrostowo n. dzierż. od n. os. Chrost (por. Stephanus Chrost 1403 TS). Człon wyróżniający Wielkie dziś zanikł.

Chrzanowo okolica szlachecka obejmująca niegdyś wsie: Ch.-Cyprki, Ch.-Dusze, Ch. Nadolne, Ch.-Nowiny, Ch.-Wypychy, dziś tylko Chrza-

14 Polskie nazwy..., op. cit., s. 207. 
nowo, pow. Łomża, gm. Przytuły: SG I 651; Kap nr 65; de Chrzanovo 1524 MZH nr 992; Chrzanowo Wipichi 1577 ŹDz XVI 359; Zierh 136; Hal Bł I 36. Chrzanowo n. dzierż. od n. os. Chrzan (por. Joannes Crzan 1467 TS).

Dłużniewo wś szlach (1421), pow. i gm. Łomża: "Jest to gniazdo Dłużniewskich, wspomniane w aktach w 1421 roku" SG II 42; Kap nr 100; Glog 11; de Dlusznyewo 1463 MZH nr 221; Dluzniewo 1578 ŹDz XVI 368; Zierh 154; Hal Bł I 44. Dłużniewo n. dzierż. od n. os. ${ }^{*} D \nmid u-$ żen//Dłużeń (por. czes. dlużen 'winien', rus. ja dołżeń 'winien', 'muszę' Brück 90).

Drogoszewo wś szlach (1676), pow. Łomża, gm. Miastkowo: „Jest to gniazdo rodu Drogoszewskich lub Drogożewskich" SG II 148; Glog 11; 1578 ŹDz XVI 383; Hal Bł I 48. Zierh nie podaje nazwy tej wsi. Drogoszewo n. dzierż od n. os. Drogosz ( $\leq$ Drogomir, Drogosław). Por. Drogos 1265 TS.

Głodowo-Dąb wś szlach. (1457), pow. Zambrów gm. Kołaki Kościelne: "Jest to stare gniazdo Głodowskich, wspomniane w dokumentach w 1457 roku" SG II 603; Glog 12; Kap nr 138; Hal Bł I 57; Zierh nie podaje tej nazwy w pow. Zambrów czy Łomża. Wymienia parę nazw wsi Głodowo w pow. Pułtusk. Głodowo n. dzierż. od n. os. Głód (por. np. advocatus Visznensis Gloth 1426 MkM I nr 370). Dab n. top. od n. rzeczki $D q b$, nad którą wieś założono.

Janczewo wś szlach., pow. Łomża, gm. Jedwabne: SG III 387; Ianczewo 1430 MkM II nr 622; de Janczewo 1489 MZH nr 687; Janczewo 1577 ŹDz XVI 355; Zierh 196; Hal Bł I 70. Janczewo n. dzierż. od im. Janczy ( $\leq$ Jan).

Janikowo dziś Jankowo-Młodzianowo, J.-Skarbowo wsie szlach. pow. Łomża, gm. Nowogród: SG III 411; Ianikowo 1426 MkM I nr 234; Kyelcz de Janicowo 1446 MZH nr 48; Jankowo (Magna, Kielcze, Mlodzianowo, Dominikowo); Zierh 197; Hal Bł I 70. Janikowo n. dzierż. od im. Janik ( $\leq$ Jan). Młodzianowo n. dzierż. od n. os. *Młodzian, Skarbowo n. dzierż od im. Skarb ( $\leq$ Skarbimir, Skarbisław). Por. ${ }^{*}$ Skarbisław ${ }^{15}$.

Karwowo-Wszebory, (-Polki) wś szlach. i włośc. (1423), pow.

15 M. Karaś, O staropolskich imionach dwuczłonowych zachowanych $w$ nazwach miejscowych, "Onomastica" 2, 1956, s. 269. 
Łomża, gm. Jedwabne: SG III 892; Glog 12; Kap nr 209; de Carwovo 1476 MZH nr 475; Carwowo (Stryaski, Kubrzane, Korpisze, Zabłocie, Wsebori) 1577 ŹDz XVI 357, 358; Zierh 207-208; Hal Bł I 77. Karwowo n. dzierż. od n. os. ${ }^{*} K a r w$. Wszebory część wsi Karwowo, n. rod. od im. Wszebor TNaj 28, Polki dziś nie istniejąca n. rod. od im. Polik $(\leq$ Polikarp). Por. im. Polich TNaj 49.

Kotowo-Plac wś szlach i włośc. (1453), pow. Łomża, gm. Jedwabne: SG IV 498; Kap nr 241; de Kothowo 1478 MZH nr 523; de Cotovo 1532 MZH 1027; Cotowo 1577 ŹDz XVI 356; Zierh 224; Hal Bł I 91. Kotowo n. dzierż. od n. os. Kot (por. Nicolaus Koth de Lutostan $1470 \mathrm{MZH}$ nr 328). Plac n. top.

Krajewo: Białe, Borowe, -Budziły, -Ćwikły, -Korytki, -Łętowo, Stare wsie szlach. (1413), pow. i gm. Zambrów: „Okolica szlachecka w dawnej ziemi łomżyńskiej” SG IV 582; Glog 13; Kap nr 277; de Crayewo 1479 MZH nr 542; de Byale Crayewo 1506 MZH nr 850; Craievo Brzozowo 1578 ŹDz XVI 377; „Krajewo, kilka wsi w pow. łomżyńskim, gm. Zambrów" Zierh 227; Hal Bł I 93-94. Krajewo n. dzierż. Człony wyróżniające nazw wsi mają tu różne znaczenie: Białe i Borowe n. top. określające właściwość terenu; Budziły, Ćwikły i Korytki n. rod. wskazujące właściciela wsi lub jej części, utworzone kolejno od im. Budza ( $\leq$ Budzisław), od n. os. Ćwikło, Korytko, Łętowo n. dzierż. od n. os. “ Łęt (por. gw. łęt 'łodyga ziemniaczana').

Łętowo-Dąb wś szlach. (1444), pow. Zambrów, gm. Kołaki Kościelne: SG V 667; Glog 13; Kap nr 309; de Lanthowo 1469, $1480 \mathrm{MZH}$ nr 318, 571; Lentowo 1578 ŹDz XVI 381; Zierh 247; Hal Bł I 107. Łętowo n. dzierż. od n. os. *Łęt (por. stpol. Łęt 'pręt', gw. łęt 'łodyga ziemniaka'). $D a b$ n. top. od n. rzeczki Dąb.

Maliszewo-Perkusy, -Łynki wś szlach (1430), pow. Białystok, gm. Zawady: SG XVI 19; Glog 13; Kap nr 320; Malisewo 1578 ŹDz XVI 33; Hal Bł I 112. Zierh nie podaje nazwy tej wsi w ziemi łomżyńskiej. Wymienia te nazwy w pow. Płock, Pułtusk. Maliszewo n. dzierż. od im. ${ }^{*}$ Malesz ( $\leq$ Małomir). Łynki, Perkusy n. rod.

Małochowo dziś Małachowo wś szlach., pow. Łomża; gm. Wizna: SG VI 26; Malochowo 1577 ŹDz XVI 355 Hal Bł I 112. Zierh wymienia taką nazwę wsi tylko w pow. Płock. Małochowo n. dzierż. od im. Małoch (< Małomir), por. TNaj 49 . 
Miastkowo wś szlach. (1413), pow. Łomża, gm. Miastkowo: SG VI 289; "g. [gniazdo] Miastkowskich" Glog 13; de Myasthcowo 1446 MZH nr 48; Miastkowo 1578 ŹDz XVI 368; Zierh 257; Hal Bł I 114. Miastkowo n. dzierż. od n. os. * Miastko (por. zdr. miastko od miasto).

Milewo (-Sokolałąka) wś szlach. i włośc. (1414), pow. i gm. Łomża: SG VI 424; Kap nr 329; Glog 13; de Mylewo 1462 MZH nr 209; Milewo Sokolałąka 1578 ŹDz XVI 370; Zierh 261; Hal Bł I 117. Milewo n. dzierż. Sokolałąa $\mathrm{n}$. top. dziś nie funkcjonuje.

Niewodowo wś szlach. i włośc. (1417), pow. Łomża gm. Piątnica: "Mieszka tu w części drobna szlachta, a w części włościanie" SG VII 138; Kap nr 360; de Niewodowo 1510 MZH nr 877; Niewodowo 1577 ŹDz XVI 357; Zierh 279; Hal Bł I 128. Niewodowo n. dzierż. od n. os. *Niewod (por. niewód 'sieć rybacka').

Rakowo-Boginie (-Czachy) wś szlach. (1433), pow. Łomża, gm. Piątnica: SG IX 518; Glog 14; Kap nr 453; de Rakovo 1510 MZH nr 877; Rakowo Czachi 1577 ŹDz XVI 355; Rakowo Boginie 1577 ŹDz XVI 357; Zierh 315; Hal Bł I 145. Rakowo n. dzierż. Boginie n. rod. od n. os. *Boginia ( $\leq$ Boguchwat, Bogumit), Czachy n. rod. od n. im. Czach ( $\leq$ Czastaw), dziś nazwa z tym członem wyróżniającym nie występuje.

Rębiszewo-Zegadły wś szlach., pow. Zambrów gm. Kołaki Kościelne: „Mieszka tu częściowa szlachta”; SG IX 610, Glog 14; Gregorius Rambischewsky, Johannes Zegadlo armorum Prussy 1466 MZH nr 268; de Rambyschewo 1511 MZH nr 92; Zegadli Rembisewo 1578 ŹDz XVI 380-381; Zierh 318-319; Hal Bł I 146. Rębiszewo n. dzierż., Zegadty n. rod. od n. os. Żegadło.

Strękowo, dziś Strękowa Góra wś szlach. (1443), pow. Białystok, gm. Zawady: "g. Strękowskich h. Grzymała” SG XI 401, Glog 14; Kap nr 516; Petrus Godzeba de Strankovo 1446 MZH nr 43; Strenkowo 1578 ŹDz XVI 379; Zierh 348, Hal Bł I 161. Strękowo n. dzierż. od on. os. Strąk (por. Strank de Brolino $1426 \mathrm{MkM}$ I nr 261). Góra n. top.

Somowo, dziś Szumowo, Sz. Nowe, wś szlach. (1454), pow. Zambrów, gm. Szumowo: SG XII 76; Glog 14; de Somowo 1454 MZH nr 104; Somowo 1578 ŹDz XVI 370; Zierh 343; Hal Bł I 169. Somowo n. dzierż. od n. os. ${ }^{*}$ Som.

Tarnowo-Goski wś szlach. (1417), pow. i gm. Zambrów: SG XII 209; Glog 14; Tarnowo-Goski 1578 ŹDz 381; Hal Bł I 173. Zierh (381) wymie- 
nia taką nazwę wsi tylko w gm. Miastkowo, pow. Łomża. Jest to nazwa folwarku szlacheckiego. Tarnowo n. dzierż. od n. os. ${ }^{*}$ Tarn (por. Stanisław Tarn $\left.1397{ }^{16}\right)$.

Wirciszewo, dziś Wierciszewo wś szlach., pow. Łomża, gm. Wizna: SG XII 385; de Wyrczyschewo 1465 MZH nr 250; Wierciszewo 1577 ŹDz XVI 357; Zierh 378; Hal Bł I 182. Wierciszewo n. dzierż. od im. Wircisz ( $\leq$ Wirciżyr TNaj).

Nazwy dzierżawcze z sufiksem -owo//-ewo derywowane są od różnych podstaw:

1) od nazw osobowych odapelatywnych, np.:

$\begin{array}{ll}\text { Brzostowo } \leftarrow \text { Brzost, } & \text { Chmielewo } \leftarrow \text { Chmiel, } \\ \text { Chrostowo }- \text { Chrost, } & \text { Chrzanowo }- \text { Chrzan, } \\ \text { Eętowo } \leftarrow{ }^{*} \text { Eęt; } & \text { Niewodowo } \leftarrow \text { Niewód; }\end{array}$

2) od imion dwuczłonowych skróconych i spieszczonych, np.:

Braciszewo (dziś Brajczewo) - Bracisz ( $\leq$ Bratumit),

Drogoszewo $\leftarrow$ Drogosz ( $\leq$ Drogomir, Drogosław),

Maleszewo (dziś Maliszewo) $\leftarrow{ }^{*}$ Malesz ( $\leq$ Małomir),

Małochowo $\leftarrow$ Małoch ( $\leq$ Małomir),

Wirciszewo (dziś Wierciszewo) $\leq$ Wircisz ( $\leq$ Wircyżyr);

3) znacznie rzadziej od imion jednoczłonowych skróconych, np.:

Janczewo $\leftarrow$ Jancza $(\leq$ Jan),

Janikowo (dziś Jankowo) ־Janik $(\leq$ Jan $)$.

\section{Nazwy z sufiksem -in- (-yn-)}

Nazwy dzierżawcze tworzone formantem -in-stanowią w analizowanym materiale 18,5\% ogółu omawianych nazw wskazujących właściciela osady. Występują tu wyłącznie formy męskie z -in (np. Brulin, Drożęcin, Mężenin) i -yn przy podstawie kończącej się na spółgłoskę stwardniałą (Kałęczyn, Skarżyn). Tylko dwie nazwy mają formę liczby mnogiej z sufiksem -iny (Chyliny, Sasiny).

Brodlino, Brolino, Brulino, dziś Brulin wś szlach., pow. Łomża, gm. Śniadowo: SG I 387; Glog 11; Brolino 1425 MkM I nr 90; de Brolino

16 W. Taszycki, Rzekomo dzierżawcze..., op. cit., s. 105. 
1462 MZH nr 206; Brolino 1578 ŻDz XVI 318; Hal Bł I 26. Zierh nie podaje nazwy tej wsi w pow. łomżyńskim. Wymienia ją tylko w pow. Pułtusk. Brodlino n. dzierż od im. Brodla ( $\leq$ Brodzisław). Zmianę postaci nazwy wywoływały różne zjawiska językowe m.in.: uproszczenie grupy spółgłoskowej $-d l-\geq l$, podwyższenie artykulacji głoski $o$ przed $l$ $(o \geq u)$, zmiana rodzaju nazwy (-ino $\geq-i n)$.

Chylino, dziś Chyliny (-Kąty, -Wity) wś szlach. (1436), pow. Łomża, gm. Jedwabne: SG I 668; Kap nr 66; de Chilini 1525 MZH nr 1001; Chilini (Kąnthi, Witti) ŹDz XVI 359; Zierh 137; Hal Bł I 37. Chyliny n. dzierż. od n. os. Chyla. Hal Bł: n. rod. Nazwy członów wyróżniających, dziś już nie istniejące, oznaczały: Kąty n. top. określająca położenie wsi, Wity od im. nowego właściciela wsi lub jej części.

Drożęcino, dziś Drożęcin-Lubiejewo, D. Stary wś szlach. (1411), pow. Łomża, gm. Piątnica: SG II 164; Glog 11; „Dom Drożęckich h. Trzaska" Kap nr 106; Ratiborius Drozanczki 1426 MkM I nr 261; Droszanczyno 1479 MZH nr 554; Drozenczino 1577 ŹDz XVI 337; Zierh 161; Hal Bł I 48. Drożęcin n. dzierż. od im. Drożęta ( $\leq$ Drogomyst, Drogosław). Lubiejewo n. dzierż. od n. herbu Lubiewo.

Kałęczyno, dziś Kałęczyn wś szlach. (XVI w.), pow. Zambrów, gm. Rutki-Kossaki: SG III 719; Glog 12; de Kalaczino 1505 MZH nr 843; Kalanczyno 1578 ŹDz XVI 314. Zierh wymienia taką nazwę wsi tylko w pow. Pułtusk. Hal Bł I nie podaje nazwy tej wsi. Kałęczyn n. dzierż. od n. os. Kałak (por. ap. kabłak).

Kobylino, dziś Kobylin wś szlach. (1421), pow. Łomża, gm. Piątnica: "gniazdo Kobylińskich h. Pobóg” SG IV 215; Glog 12; „Stanislaus Pirog de Kobylino" Kap nr 221; de Cobyle $1471 \mathrm{MZH}$ nr 375; Kobylino 1577 ŹDz XVI 357; Hal BŁ I 81, 82. Zierh wymienia takie nazwy tylko w pow. Ciechanów i Maków. Kobylino n. dzierż. od n. os. Kobyła (por. Dobco dictus Cobila 1404 TS).

Mężenino, dziś Mężenin wś szlach. (1423), pow. Łomża, gm. Śniadowo: „Mieszka tu drobna szlachta; starożytne gniazdo Mężeńskich, wspomniane w aktach w 1423 roku” SG VI 281; "dwie są wsie tego nazwiska" Grog 13; Mązenyno 1475 MZH nr 467; Męzenino 1578 ŹDz XVI 379; Hal Bł I 114. Zierh wymienia taką nazwę wsi tylko w obecnym pow. Zambrów. Mężenino n. dzierż. od n. os. ${ }^{*}$ Mężyna, urobionej od n. ap. $m a \dot{z}$. 
Mężenino, dziś Mężenin wś szlach., pow. Zambrów, gm. Rutki-Kossaki: SG VI 281; Glog 13; „Dom Mężeńskich h. Kościesza” Kap nr 335; de Manzenyno $1462 \mathrm{MZH}$ nr 209; Męzenino Antiqua, Nova 1578 ŹDz XVI 379; Zierh 256; Hal Bł I 114. Mężenino n. dzierż. od n. os. *Mężyna.

Skarżyno, dziś Skarżyn Stary, Nowy wś szlach. (1432), pow. i gm. Zambrów: SG X 657; Glog 14; Kap nr 485; de Skarzyno 1430 MkM II nr 617-618; Skarzino 1578 ŹDz XVI 404-405; Hal Bł I 158. Zierh nie podaje takiej nazwy wsi w pow. Zambrów. Wymienia je w pow. Płońsk i Ostrołęka. Skarżyno n. dzierż. od n. os. Skarga.

Nazwy dzierżawcze derywowane formantem -in- najczęściej motywowane są:

1) nazwami osobowymi odapelatywnymi np.

Kałęczyno, Kałęczyn - n. os. Kałak (od ap. kabłak);

Kobylino, dziś Kobylin - n. os. Kobyła (od ap. kobyła);

Mężenino, dziś Mężenin - n. os. ${ }^{*}$ Mężyna (od ap. mąż);

2) imionami dwuczłonomi skróconymi i spieszczonymi, np.:

Brodlino, dziś Brulin - im. Brodla ( $\leq$ Brodzisław);

Drożęcino, dziś Drożęcin - im. Drożęta (< Drogomyst, Drogosław).

\section{Nazwy z sufiksem ${ }^{*}-j b\left({ }^{*}-j e\right)$}

Nazwy tworzone sufiksem *-jь (m.), *-je (n.) stanowią 10,3\% analizowanego materiału. Mają one przede wszystkim formę rodzaju męskiego (np. Lutostań, Tabędz), tylko w dwóch wypadkach formę nijaką (Czochanie, Zanie).

Czochań, dziś Czochanie-Góra wś szlach (1423), pow. Zambrów, gm. Rutki-Kossaki: „Dawna okolica szlachecka” SG I 867; Glog 11; Kap nr 78; Czochanie 1425 MkM I nr 260; Paulus Czochanysky $1462 \mathrm{MZH}$ nr 204; Czochanie 1578 ŹDz XVI 379; Zierh 147; Hal Bł I 42. Czochanie n. dzierż. od im. imiesłowowego ${ }^{*}$ Czochan. Góra n. top.

Lutostań wś szlach. (1473), pow. i gm. Łomża: SG V 491; Glog 13; Nicolaus Habrae Koth de Luthostan 1470 MZH nr 328; Lutostań 1578 ŹDz XVI 378; Zierh 243; Hal BŁ I 105. Lutostań n. dzierż. od im. *Lutostan.

Siemień Nadrzeczny, S.-Rowy (Szlachecki) wś szlach. i włośc. (1431), pow. i gm. Łomża: Siemień Szlachecki (nazwa dziś nie istniejąca) 
„zamieszkały przez drobną szlachtę" SG X 544; Glog 14; de Szemen 1426 MkM I nr 357; de Syemyen 1510 MZH nr 877; Siemień 1578 ŹDz XVI 367; Zierh 331; Hal Bł I 154. Siemień od im. Siemian TNaj ( $\leq$ Siemimyst, Siemowit). Nadrzeczny, Rowy n. top. wskazujące położenie wsi.

Sławcz, dziś Sławiec wś szlach. i włość. (1466), pow. Łomża, gm. Nowogród: SG X 780; Glog 14; „Dom Sławskich h. Mora” Kap nr 501; de Slawcz MkM I nr 472; Slawcz 1578 ŹDz XVI 369; Zierh 337; Hal Bł I 159. Sławcz n. dzierż. od im. Sławk, Sławek ( $\leq$ Sławomir).

Tabędz wś szlach., pow. i gm. Zambrów: SG XII 134; Glog 14; Vlodek de Thabąndz 1462 MZH nr 199; Tabądz 1578 ŹDz XVI 378; Zierh 364; Hal Bł I 172. Tabqqdz n. dzierż. od n. os. ${ }^{*}$ Tabqqd + sufiks ${ }^{*}-j b$.

Wyszemirze, Wyszemirz, dziś Wyszomierz Wielki wś szlach., pow. Zambrów, gm. Szumowo: SG XIV 156; Wyschemyrz 1430 MkM II nr 188; Wyssemierze Antiqua, Nowa 1578 ŹDz XVI 404; Zierh 386; Hal Bł I 189. Wyszemirze n. dzierż. od im. Wyszemir.

Żanie, dziś Zanie-Leśnica wś szlach. (XVI w.) gm. Kołaki Kościelne, pow. Zambrów: SG XIV 391; Glog 15; de Zanye 1487 MZH nr 670; Żanie Lesnicza 1578 ŹDz XVI 380; Zierh 399. Hal Bł nie podaje nazwy tej wsi. Żanie n. dzierż. od n. os. ${ }^{*}$ Żan. Zmiana Żanie $\geq$ Zanie jest zapewne wynikiem mazurzenia. Leszcznica, Leśnica n. top. od n. strumienia (por. riwolo Lesznicza 1426 MKM I nr 319).

Podstawę nazw derywowanych za pomocą formantu ${ }^{*} j b\left({ }^{*}-j e\right)$ stanowią:

1) imiona lub nazwiska jednoczłonowe:

Lutostań od im. * Lutostan,

Czochań, Czochańce od im. Czochan,

Żanie, Zanie od n. os. *Żan (por. Tomasz Zan);

2) imiona dwuczłonowe, skrócone:

Siemień od im. Siemian TNaj ( $\leq$ Siemistaw, Siemowit),

Sławcz, Sławiec od im. Sławk, Sławek ( $\leq$ Sławomir).

\section{Nazwy tworzone przy użyciu innych formantów}

Nazwy dzierżawcze derywowane za pomocą innych sufiksów stanowią tylko 4,6\% analizowanego materiału. Tworzą je dwa sufiksy: -ski -ck-, stosunkowo rzadko występujące w nazwach dzierżawczych. 
Górki, dziś Górskie-Ponikły Stok wś szlach. (XV w.), pow. Zambrów, gm. Rutki-Kossaki: SG II 724; Glog 12; Kap nr 139; de Pomyklyshok 1475 MZH nr 470; Gorki Poniklistok 1578 ŹDz XVI 379; Zierh 184; Hal Bł I 61. Górki n. rod. od n. os. Górka, Górskie n. dzierż., Ponikły Stok n. top. od nazwy strumienia.

Makowe, Makowo, dziś Makowskie wś szlach. (1465), pow. Łomża, gm. Jedwabne: SG V 935; „Dom Makowskich h. Jelita” Kap nr 319; de Macove 1531 MZH nr 1014; Makowo Bure 1577 ŹDz XVI 359; Zierh 251; Hal Bł I 111. Makowe n. dzierż. od n. os. Mak (por. np. Petri Makow 1579 ŹDz XVI 181).

Biezdziedze, dziś Przeździecko-Mroczki wś szlach. (XV w.), pow. i gm. Zambrów: SG IX 190; Glog 14, Besdecce MkM I nr 177; Przezdzieczk (Mroczki) ŹDz 1578 XVI 381; Zierh 112. Hal Bł nie podaje nazwy tej wsi. Biezdziedze n. dzierż. od im. Biezdziad TNaj 35, obok Biezdziad im. Przezdziad TNaj 36. Zmiana Biezdziedze $\geq$ Przezdziecko polega na wymianie przedrostków Biez- $\geq$ Przez- i dodaniu sufiksu -sko $\geq$-cko. Mroczki n. rod. od n. os. Mroczek.

Nazwy tworzone przy użyciu przyrostków -sk-, -ck- motywowane są nazwami osobowymi:

Górskie - Górka, Makowe -Mak, Przezdziecko — Przezdziad.

$\mathrm{Na}$ podstawie przeprowadzonej analizy nazw dzierżawczych w Łomżyńskiem, dochodzimy do następujących wniosków:

1. Nazwy te są tworzone przy użyciu niewielkiej liczy przyrostków. Nie są tu wykorzystywane w pełni trzy rodzaje gramatyczne i dwie liczby sufiksów:

a) sufiks -ov-//-ev- występuje tylko w nazwach o rodzaju nijakim,

b) sufiks -in- notujemy wyłącznie $w$ nazwach rodzaju męskiego. $\mathrm{W}$ historycznym rozwoju nazw przekształciły się one $\mathrm{z}$ form rodzaju nijakiego w rodzaj męski. Tylko w dwóch wypadkach mają formy liczby mnogiej (Chyliny, Sasiny),

c) sufiks * ${ }^{*}$ b tworzy przede wszystkim nazwy rodzaju męskiego, tylko dwie nazwy mają formę rodzaju nijakiego (Czochanie, $\mathrm{Za}$ nie).

2. Nazwy dzierżawcze derywowane są na ogół od imion i nazwisk odapelatywnych, stosunkowo często od imion dwuczłonowych skróconych i spieszczonych. 
3. W ostatnich dziesięcioleciach w nazewnictwie wsi drobnej szlachty zaszły znaczne zmiany. Nazwy wsi lub ich części powstałe $\mathrm{z}$ działów w wielu wypadkach dziś już nie istnieją. W ślad za tym w nazwach złożonych zanikają człony wyróżniające, które przez wielu badaczy uznawane są za wyznaczniki wsi szlacheckich.

Oto wybrane przykłady ilustrujące omawiany proces:

Chrzanowo, dziś jedna wś szlach. w pow. Łomża, w gm. Przytuły. Jeszcze w Słowniku geograficznym Królestwa Polskiego (SG I 651) nazwą tą obejmowano „okolicę szlachecką", a w niej wsie: Ch. Cyprki, Ch.-Dusze, Ch. Nadolne, Ch.-Nowiny, Ch.-Wypychy.

Janikowo, dziś wś szlach. Jankowo-Młodzianowo, J.-Skarbowo w pow. Łomża, gm. Nowogród. Źródła dziejowe... A. Pawińskiego (1578 ŹDz XVI 369) wymieniają cztery nazwy wsi z członem utożsamiającym Jankowo (Magna, Kielcze, Mlodzianowo, Dominikowo).

Karwowo, dziś Karwowo-Wszebory wś szlach. w pow. Łomża, gm. Jedwabne. Źródła dziejowe... A. Pawińskiego (1577 ŹDz XVI 357-358) podają takie nazwy wsi: K.-Stryjaki, K. Kubrzane, K. Korpisze, K.-Wsebori, K.-Zabłocie). Część z nich (Korpisze, Zabłocie) już nie istnieje, część (Kubrzany, Stryjaki, Wszebory) to nazwy rodowe wsi bez członu utożsamiającego Karwowo.

4. W ciągu wieków funkcjonowania nazw miejscowych zachodziły w nich procesy fonetyczne i słowotwórcze. Szczegółowy ich opis mógłby stanowić przedmiot odrębnego opracowania, tu zatem zasygnalizuję tylko niektóre $\mathrm{z}$ nich.

Najczęstsze zmiany słowotwórcze polegają na wymianie przyrostków, która albo nie powoduje zmiany typu nazwy, jak w nazwach dzierżawczych tworzonych sufiksem -ino $\geq$ in Kobylino $\geq$ Kobylin,

bicz- $\geq$ przez (Biczdziedze - Przezdziecko)

$-e c \geq$-owo (Brzostowiec - Brzostowo)

albo powoduje zmianę typu nazwy, czyli przekształcenie nazw dzierżawczych w rodowe np. Korytkowo - Korytki-Leśne, Szabłowo - Szabły, Zarębino - Zaręby.

Najczęściej notowane zjawiska fonetyczne to zmiana artykulacji samogłosek, zwłaszcza ich rozszerzenie lub ścieśnianie, np. o do $a$ : Małochowo - Małachowo, o do u: Szomowo - Szumowo, e do i: Maleszewo Maliszewo oraz uproszczenia grup spółgłoskowych: -dl- $\geq-l$ : Brodlino - 
Brulino. Mamy też przykład odmiennej realizacji kontynuantów dawnego sonantu przedniego Wirciszewo - Wierciszewo, Wyrzomirz - Wyszomierz)

Wykaz skrótów wykorzystanych źródeł

Brück - A. Brückner, Słownik etymologiczny języka polskiego, Warszawa 1993.

Glog - Z. Gloger, Dawna ziemia łomżyńska, „Biblioteka Warszawska", t. 2, Warszawa 1976, s. 579-595, przedruk Łomża 1986.

Hal Bł I, II - I. Halicka, Nazwy miejscowe środkowej i zachodniej Białostocczyzny, cz. 1-2, Warszawa 1976, 1978.

Kap - I. Kapica-Milewski, Herbarz, Kraków 1870.

MkM - Metryka Księstwa Mazowieckiego z XV-XVI wieku, wyd. A. Włodarski, t. 1-2, Warszawa 1918, 1930.

MZH - A. Wolff, Mazowieckie zapiski herbowe z XV i XVI wieku, Kraków 1937.

SG - Słownik geograficzny Królestwa Polskiego i innych krajów słowiańskich, t. 1-15, Warszawa 1980-1902.

TNaj - W. Taszycki, Najdawniejsze polskie imiona osobowe, Kraków 1925.

TS - W. Taszycki, Słownik staropolskich nazw osobowych, t. 1-3, Wrocław - Warszawa Kraków 1965-1971.

ŹDz - A. Pawiński, Polska XVI wieku pod względem geograficzno-statystycznym. Mazowsze. Źródła dziejowe, t. XVI, Warszawa 1892.

Rozwiązanie innych skrótów
h. - herb
n. rod. - nazwa rodowa
im. - imię
n. top. - nazwa topograficzna
n. ap - nazwa apelatywna
wś szlach. - wieś szlachecka
n. dzierż. - nazwa dzierżawcza
wś włośc. - wieś włościańska 